\title{
A Study Of The Role Indian Accountants In Managerial Decision Making
}

Melkote K. Shivaswamy, (E-mail: mshivasw@bsu.edu), Ball State University R. S. Rathinasamy, (E-mail: rsrathin@bsu.edu), Ball State University

\begin{abstract}
This paper studies the extent of participation of accountants in the managerial decision making process in India. In general, accountants had the most influence over decisions relating to management information systems (MIS), financing, production, resource allocation, new product introduction and discontinuance of old products. They had the least influence over decisions relating to marketing and personnel. For some of the decision variables studied, professional experience and size of firm were significant factors affecting responses. Factor and cluster analyses identified two distinct factors/clusters: a participation factor/cluster consisting of eight of the nine participatory variables studied, and a MIS-budgeting factor/cluster consisting of usefulness of the budget, involvement in MIS decisions, and the level of top management support.
\end{abstract}

\section{INTRODUCTION AND OBJECTIVES}

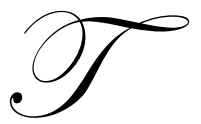

raditionally, most organizations have made a distinction between line and staff functions. Line management has had direct responsibility for the attainment of objectives of the firm whereas staff management has had the function of advising and assisting line management. By these definitions, accounting would be a staff function with responsibility for score keeping and providing information to management. Lately, many businesses have stressed the importance of cross-functional teams in attaining the objectives of the corporation. The traditional distinction between line and staff is no longer hard and fast and, increasingly, the accountant is being considered a member of the management team with shared responsibility for managerial decision-making (Lander, et.al., 1983). In particular, management accountants are playing a larger and important role in organizations; they are participating in various organizational activities such as strategic planning, process improvement, customer and product profitability analysis, and mergers and acquisitions (Russell et. al., 1999). Increasingly, management accountants see themselves as facilitators of managerial decision-making and interpreters and analyzers of data and are greatly involved in financial planning and modeling. The management accounting profession has entered the realm of financial management, business strategy, information technology and information management (Kulesza and Siegel, 1997). Management accountants are also heavily involved in capital investment decision-making (Prendergast, 1998). The work of the management accountants has become more analytical and decision centered. For example, in a 2001 study of Institute of Management Accountants, more than $80 \%$ of the accountants surveyed expected to spend more time interpreting and analyzing information in the next three years. They also expected to be much more involved in strategic decision-making (Siegel, 2001). According to Latshaw and Choi (2002), accountants have become part of the management team. They point out that terms such as "strategic partner" and "business partner" emphasize the enhanced roles accountants play in today's organizations.

In their drive to cut costs and remain competitive, American multinational corporations have been expanding their operations around the globe and especially in Asia with several distinct advantages. With a population of over a billion, an educated and well-trained workforce, a stable democracy, a fairly well established legal system, a growing affluent middle class, liberal economic policies, and a fast growing economy, India has become a favorite destination of U.S. multinationals where they have set up their operations, facilities, and plants in India. In the light of these developments, it is necessary to examine the Indian business climate in general and the accounting practices and the role of Indian accountants in particular. 
The research done by others highlight the enhanced and important role of American accountants in the managerial decision making process. However, there has been no systematic study of the role of Indian accountants in managerial decision-making. Our current research addresses this gap in the literature and provides important insights into the extent of participation of the Indian accountants in the managerial decision-making.

We surveyed accountants in India from small, medium, and large corporations from various industrial sectors. The survey included respondents working both in the private and public sectors of industry in the city of Bangalore. Specifically, our study examines the role of accountants in India in management, their influence on various decision processes, the degree of their participation in long-range or strategic planning, development of new products or services, discontinuance of certain existing products or services, allocation of a company's scarce resources, financing, marketing and production decisions, and planning, designing and setting up management information systems (MIS).

\section{METHODOLOGY}

\section{Questionnaire Survey}

In this study, we use a mail-in questionnaire survey method. The original survey was conducted in the city of Bangalore in 1993 and updated in 1996. Often referred to as the silicon valley of India, this city of over four million people is one of the fastest growing metropolises in Asia. Bangalore is also home to a number of multinational businesses making it a place of strategic importance. It is also home to a variety of industries, and therefore is quite representative of the entire nation

A stratified random sampling procedure was used to select the sample of respondents. Questionnaires were mailed to 250 accountants. The number of completed questionnaires returned was 118 , giving us an overall response rate of 47 percent. Nine questions were chosen specifically by the authors to elicit the role of accountants in managerial decision-making. Respondents were asked to indicate on a five-point scale the extent of their participation in making each of nine types of decisions. The higher the number, the greater was their extent of participation in the decision-making process. We interpret a score of 3 to mean they participated, a score of 4 or 5 to mean that they greatly participated, and a score of 1 or 2 to mean they had little or no participation, in the decisionmaking process. The mail-in questionnaire survey instrument is available from the authors.

\section{Null Hypotheses}

H01: There are no significant differences in the participation rates of accountants among different functional areas.

H02: Professional accounting certification will not increase the participation rate of accountants.

H03: Greater experience will not increase the participation rate of accountants.

H04: Larger firm size will not increase the participation rate of accountants.

\section{Frequency Distribution Analysis}

The frequency distribution of the participation variables was analyzed using FREQ procedure in Statistical Analysis System (SAS). Further cross-tabulation of the participation variables was done by using the TABLES Procedure in SAS.

\section{Factor Analysis}

A factor analysis of participation of accountants in managerial decisions was done to gauge the importance of each of the nine participation variables studied; an orthogonal rotation method was employed. The following three additional variables that we considered to be relevant were included in the factor analysis:

- $\quad$ Process of capital budgeting decision - democratic versus autocratic

- $\quad$ Level of top management support for the budgeting process and

- $\quad$ Usefulness of the budgeting process 


\section{Cluster Analysis}

A cluster analysis of the variables used in factor analysis was also done to develop non-overlapping onedimensional clusters; the output data from the factor analysis was used. This was done as a way to reduce the number of variables in the study and identify clusters of decision variables that go together. Clusters, then, can be easily interpreted. The VARCLUS procedure in SAS was used to create a linear combination of disjoint clusters.

\section{RESULTS AND DISCUSSION}

\section{Profile of Accountants Surveyed}

A profile of respondents is presented in Table 1 . Of the 118 respondents, $97.5 \%$ were male; a majority $(52.54 \%)$ were from the $35-45$ year group. $96.61 \%$ of the accountants surveyed had a college degree; a great majority of them (78.81\%) were professionally certified. Forty-three percent of the respondents had between 8 to 15 years of experience on the job. Sixty-eight percent of the accountants were from the public sector and the remaining $32 \%$ of the accountants were from the private sector. Thirty-three percent of the accountants worked in small firms, $28.81 \%$ worked in medium size firms, and the remaining $38.14 \%$ worked in large firms.

Table 1: Profile Of Respondents

\begin{tabular}{|c|c|c|c|}
\hline \multicolumn{4}{|l|}{ Characteristic } \\
\hline 1. Sex & \multicolumn{2}{|l|}{ Male } & Female \\
\hline & $115(97.5 \%)$ & \multirow[b]{2}{*}{$35-45$ years } & $3(2.54 \%)$ \\
\hline \multirow[t]{2}{*}{ 2. Age } & Less than 35 years & & Over 45 Years \\
\hline & $27(22.9 \%)$ & $62(52.54 \%)$ & \multirow{2}{*}{$\begin{array}{l}29(24.58 \%) \\
\text { No }\end{array}$} \\
\hline \multirow[t]{2}{*}{ 3. Degreed } & \multicolumn{2}{|l|}{ Yes } & \\
\hline & \multicolumn{2}{|c|}{$114(96.61 \%)$} & $3(2.54 \%)$ \\
\hline \multirow[t]{2}{*}{ 4. Professional Certification } & \multicolumn{2}{|c|}{ Yes } & No \\
\hline & \multicolumn{2}{|c|}{$93(78.81 \%)$} & $25(21.19 \%)$ \\
\hline \multirow[t]{2}{*}{ 5. Experience } & 1-7 Years & $8-15$ Years & Over 15 Years \\
\hline & $21(17.80 \%)$ & $50(42.37 \%)$ & \multirow{2}{*}{$\begin{array}{l}47(39.83 \%) \\
\text { Private }\end{array}$} \\
\hline \multirow[t]{2}{*}{ 6. Sector of Employment } & \multicolumn{2}{|c|}{\begin{tabular}{l|l} 
Public - Government Owned & \\
\end{tabular}} & \\
\hline & \multicolumn{2}{|c|}{$81(68.64 \%)$} & $37(31.36 \%)$ \\
\hline \multirow[t]{2}{*}{ 7. Size of the Firm } & Small & Medium & Large \\
\hline & $39(33.05 \%)$ & $34(28.81 \%)$ & $45(38.14 \%)$ \\
\hline
\end{tabular}

Numbers given are the number of respondents for given category.

\section{Results of Overall Frequency Analysis}

Results of the Chi-square analysis of the data are presented in Table 2. Of the nine items listed, the Chisquare is highest for the decisions concerning management information systems (MIS); the Chi-square value is 48.804, significant at the 1 percent level, showing that the observed frequencies are much higher than expected on the basis of chance alone. About $88 \%$ of the respondents (with a participation scale of 3 or greater) indicated they participated or greatly participated in such decisions. This had the highest mean score of 3.92 on a five-point scale. The next highest Chi-square value of 22.261, significant at the 1 percent level, is observed for participation in financing decisions. Participation in financing decisions has a mean score of 3.59 with $76 \%$ of the respondents either participating or greatly participating. Participation in production decisions has the third highest Chi-square value of 15.274, significant at the 1 percent level. Fifty-six percent of the accountants participated or greatly participated in production decisions. Participation in resource allocation decisions has the fourth highest Chi-square value of 12.974, significant at 1 percent level. Seventy-four percent of respondents either participated or greatly participated in the resource allocation decision. Product discontinuance gets a Chi-square value of 10.734, also significant at the 1 percent level, with 56 percent of the respondents reporting participation or a great degree of participation. Finally, participation in new product introduction scores a Chi-square value of 9.431, significant at 5 percent level. Thus, 
these results clearly disprove the first null hypothesis of no significant differences in the participation rates of accountants among different functional areas.

Table 2 Accountant's Participation In Managerial Decisions

\begin{tabular}{|c|c|c|c|c|c|c|c|}
\hline \multirow{2}{*}{ Participation In: } & \multicolumn{7}{|c|}{ Participation Scale } \\
\hline & 1 & 2 & 3 & 4 & 5 & Mean & Chi-Square \\
\hline $\begin{array}{r}\text { 1. Strategic } \\
\text { Planning }\end{array}$ & $\begin{array}{c}25 \\
(21.55) \\
\end{array}$ & $\begin{array}{c}16 \\
(13.79) \\
\end{array}$ & $\begin{array}{c}24 \\
(20.69) \\
\end{array}$ & $\begin{array}{c}23 \\
(19.83) \\
\end{array}$ & $\begin{array}{c}28 \\
(24.14) \\
\end{array}$ & 3.11 & 3.396 \\
\hline $\begin{array}{l}\text { 2. New product } \\
\text { Introduction }\end{array}$ & $\begin{array}{c}30 \\
(25.86) \\
\end{array}$ & $\begin{array}{c}26 \\
(22.41) \\
\end{array}$ & $\begin{array}{c}29 \\
(25.00) \\
\end{array}$ & $\begin{array}{c}13 \\
(11.21) \\
\end{array}$ & $\begin{array}{c}18 \\
(15.52) \\
\end{array}$ & 2.68 & $9.431^{*}$ \\
\hline $\begin{array}{l}\text { 3. Product } \\
\text { Discontinuance }\end{array}$ & $\begin{array}{c}30 \\
(26.32) \\
\end{array}$ & $\begin{array}{c}20 \\
(17.54) \\
\end{array}$ & $\begin{array}{c}32 \\
(28.07) \\
\end{array}$ & $\begin{array}{c}14 \\
(12.28) \\
\end{array}$ & $\begin{array}{c}18 \\
(15.79) \\
\end{array}$ & 2.74 & $10.734 *$ \\
\hline $\begin{array}{l}\text { 4. Allocation of } \\
\text { Resources }\end{array}$ & $\begin{array}{c}9 \\
(7.96)\end{array}$ & $\begin{array}{c}20 \\
(17.70)\end{array}$ & $\begin{array}{c}25 \\
(22.12)\end{array}$ & $\begin{array}{c}29 \\
(25.66)\end{array}$ & $\begin{array}{c}30 \\
(26.55)\end{array}$ & 3.45 & $12.974^{* * 6}$ \\
\hline $\begin{array}{l}\text { 5. Financing } \\
\text { Decisions }\end{array}$ & $\begin{array}{c}12 \\
(10.43) \\
\end{array}$ & $\begin{array}{c}16 \\
(13.91) \\
\end{array}$ & $\begin{array}{c}20 \\
(17.39) \\
\end{array}$ & $\begin{array}{c}26 \\
(22.61) \\
\end{array}$ & $\begin{array}{c}41 \\
(35.65) \\
\end{array}$ & 3.59 & $22.261^{\text {** }}$ \\
\hline $\begin{array}{l}\text { 6. Marketing } \\
\text { Decisions }\end{array}$ & $\begin{array}{c}22 \\
(19.47) \\
\end{array}$ & $\begin{array}{c}18 \\
(15.93) \\
\end{array}$ & $\begin{array}{c}24 \\
(21.24) \\
\end{array}$ & $\begin{array}{c}24 \\
(21.24) \\
\end{array}$ & $\begin{array}{c}25 \\
(22.12) \\
\end{array}$ & 3.11 & 1.381 \\
\hline $\begin{array}{l}\text { 7. Production } \\
\text { Decisions } \\
\end{array}$ & $\begin{array}{c}33 \\
(29.20) \\
\end{array}$ & $\begin{array}{c}16 \\
(14.16) \\
\end{array}$ & $\begin{array}{c}32 \\
(28.32) \\
\end{array}$ & $\begin{array}{c}19 \\
(16.81) \\
\end{array}$ & $\begin{array}{c}13 \\
(11.50) \\
\end{array}$ & 2.67 & $15.274^{* * *}$ \\
\hline $\begin{array}{l}\text { 8. Personnel } \\
\text { Decisions }\end{array}$ & $\begin{array}{c}19 \\
(16.81) \\
\end{array}$ & $\begin{array}{c}21 \\
(18.58) \\
\end{array}$ & $\begin{array}{c}32 \\
(28.32) \\
\end{array}$ & $\begin{array}{c}21 \\
(18.58) \\
\end{array}$ & $\begin{array}{c}20 \\
(17.70) \\
\end{array}$ & 3.02 & 5.01 \\
\hline $\begin{array}{l}\text { 9. Management } \\
\text { Information } \\
\text { Systems }\end{array}$ & $\begin{array}{c}4 \\
(3.57)\end{array}$ & $\begin{array}{c}10 \\
(8.93)\end{array}$ & $\begin{array}{c}23 \\
(20.54)\end{array}$ & $\begin{array}{c}29 \\
(25.89)\end{array}$ & $\begin{array}{c}46 \\
(41.07)\end{array}$ & 3.92 & $48.804^{* * *}$ \\
\hline
\end{tabular}

** Significant at $1 \%$ level

* Significant at $5 \%$ level

Note: Due to missing values, the number of responses may not add up to 118

\section{Results of Participation by Professional Certification, Experience and Size of Firm}

All the nine decisions were further analyzed by professional certification, age, experience, sector of employment and size of firm. In the following pages, only the significant results are reported.

\section{Financial Decision Participation by Professional Certification, Experience and Size of Firm}

The results of financial decision participation broken down by professional certification, experience, and age appear on Table 3. The Chi-square value for the participation in certification is 10.415 , significant at the 5 percent level. In the group with professional certification, $60.86 \%$ either participated or greatly participated in financial decision-making as opposed to $8.70 \%$ for the group with no professional certification. This shows that accounting certification does lead to greater participation in financial decision-making. Similarly, experience also played an important role in the accountants' participation in financial decisions. The Chi-square value for financial decision-making tabulated by experience is 17.118 , significant at the 1 percent level. Accountants with more experience participated more: $34.78 \%$ of the accountants with over 15 years of experience either participated or greatly participated in financial decisions, $29.51 \%$ of the accountants with experience between 8 to 15 years either participated or greatly participated in financial decisions, and only $11.31 \%$ of the accountants with experience between 1 and 7 years either participated or greatly participated in financial decisions. Size of the firm also is crucial in that, in general, larger the size of the firm, greater the participation in financial decision-making. The Chisquare for the financial-decision making by experience is 20.06, significant at the 1 percent level. These results disprove the null hypotheses that professional accounting certification, greater experience and larger firm size, will not increase the participation rates of accountants. 
Table 3 Financial Decision Participation By Professional Certification, Experience And Size Of The Firm

\begin{tabular}{|c|c|c|c|c|c|c|c|c|}
\hline \multirow{2}{*}{$\begin{array}{c}\text { Financial } \\
\text { Decsion } \\
\text { Participation } \\
\text { Level }\end{array}$} & \multicolumn{2}{|c|}{$\begin{array}{l}\text { Professional } \\
\text { Certification }\end{array}$} & \multicolumn{3}{|c|}{ Experience } & \multicolumn{3}{|c|}{ Size Of The Firm } \\
\hline & Yes & No & 1-7 Years & $8-15$ Years & $\begin{array}{c}\text { Over } 15 \\
\text { Years }\end{array}$ & Small & Medium & Large \\
\hline 1 & $8(6.96)$ & $4(3.48)$ & $3(2.61)$ & $8(6.96)$ & $1(0.87)$ & $3(2.61)$ & $3(2.61)$ & $6(5.22)$ \\
\hline 2 & $15(13.04)$ & $1(0.87)$ & $3(2.61)$ & $7(6.09)$ & $6(5.22)$ & $3(2.61)$ & $3(2.61)$ & $10(8.70)$ \\
\hline 3 & $12(10.43)$ & $8(0.87)$ & $5(4.35)$ & $8(6.96)$ & $7(6.09)$ & $10(8.70)$ & $3(2.61)$ & $7(6.09)$ \\
\hline 4 & $23(20.00)$ & $3(2.61)$ & 00 & $8(6.96)$ & $18(15.65)$ & $2(1.74)$ & $13(11.30)$ & $11(9.57)$ \\
\hline 5 & $35(30.43)$ & $6(5.22)$ & $8(6.96)$ & $18(15.65)$ & $15(13.04)$ & $18(15.65)$ & $12(10.43)$ & $11(9.57)$ \\
\hline Total & $93(80.87)$ & $22(19.13)$ & $19(16.52)$ & $49(42.61)$ & $47(40.87)$ & $36(31.30)$ & $34(29.57)$ & $45(39.13)$ \\
\hline Chi-Square & \multicolumn{2}{|c|}{$10.415^{*}$} & \multicolumn{3}{|c|}{$17.118^{*}$} & \multicolumn{3}{|c|}{$20.06^{* *}$} \\
\hline
\end{tabular}

** Significant at $1 \%$ level

Significant at $5 \%$ level

Note: Due to missing values, the number of responses may not add up to 118 .

New product Introduction Decision Participation by Professional Certification, Experience and Size of Firm

The results of participation in new product introduction decisions by professional certification, experience, and age appear on Table 4. The Chi-square value for new product introduction by professional certification is 11.772, significant at 1 percent level. While $42.24 \%$ of the professionally certified group either participated or greatly participated in decisions related to new product introduction, only $9.48 \%$ of the non-certified group did so. With regard to experience, the Chi-square value for new product introduction participation by experience is 20.122 , significant at 1 percent level: accountants with more experience participated more in new product introduction. Cross-tabulation of new product introduction by size of the firm has a Chi-square value of 16.10, significant at 1 percent level. While $8.62 \%$ of the accountants in small firms greatly participated, only $2.59 \%$ of the accountants in large firms did so. These results are consistent with rejection of null hypotheses two through four that professional certification, experience, and the size of the firm will not make a significant impact on the participation rates of accountants in new product introduction.

Table 4 New Product Introduction Participation By Professional Certification, Experience And Firm Size

\begin{tabular}{|c|c|c|c|c|c|c|c|c|}
\hline $\begin{array}{c}\text { Products } \\
\text { Introduction } \\
\begin{array}{c}\text { Participation } \\
\text { Level }\end{array}\end{array}$ & \multicolumn{2}{|c|}{ Professional Certification } & \multicolumn{3}{|c|}{ Experience } & \multicolumn{3}{c|}{ Size Of The Firm } \\
\cline { 2 - 9 } & Yes & No & $1-7$ Years & $8-15$ Years & $\begin{array}{c}\text { Over 15 } \\
\text { Years }\end{array}$ & Small & Medium & Large \\
\hline 1 & $18(15.52)$ & $12(10.34)$ & $9(7.76)$ & $17(14.66)$ & $4(3.45)$ & $12(10.34)$ & $4(3.45)$ & $14(12.07)$ \\
\hline 2 & $25(21.55)$ & $1(0.86)$ & $3(2.59)$ & $11(9.48)$ & $12(10.34)$ & $5(4.31)$ & $7(6.03)$ & $14(12.07)$ \\
\hline 3 & $24(20.69)$ & $5(4.31)$ & $4(3.45)$ & $10(8.62)$ & $15(12.93)$ & $7(6.19)$ & $7(6.19)$ & $10(8.85)$ \\
\hline 4 & $11(9.48)$ & $2(1.72)$ & $0(000)$ & $3(2.59)$ & $10(8.62)$ & $3(2.59)$ & $5(4.31)$ & $5(4.31)$ \\
\hline 5 & $14(12.07)$ & $4(3.45)$ & $4(3.45)$ & $8(6.90)$ & $6(5.17)$ & $10(8.62)$ & $5(4.31)$ & $3(2.59)$ \\
\hline Total & $92(79.31)$ & $24(20.69)$ & $20(17.24)$ & $49(42.24)$ & $47(40.52)$ & $37(31.90)$ & $34(29.31)$ & $45(38.79)$ \\
\hline Chi-Square & \multicolumn{3}{|c|}{$11.772^{* * *}$} & \multicolumn{3}{|c|}{$20.122^{* *}$} & & $16.10^{* *}$ \\
\hline
\end{tabular}

** Significant at $1 \%$ level

Significant at $5 \%$ level

Note: Due to missing values, the number of responses may not add up to 118 .

Allocation of Resources Participation by Professional Certification, Experience, and Size of Firm

The results of participation in the allocation of resources by professional certification, experience, and age appear on Table 5. The tabulation of allocation of resources decision by greater experience translates into greater resource allocation participation. The Chi-square for the cross-tabulation of resource allocation by size of the firm is 12. 726, which is significant at the 5 percent level. In this case, large firms seem to enjoy a slight edge in that a slightly higher percentage of managers in this group either participated or greatly participated in decisions relating to allocation of resources. 
Table 5 Allocation Of Resources Participation By Professional Certification, Experience And Size Of The Firm

\begin{tabular}{|c|c|c|c|c|c|c|c|c|}
\hline \multirow{2}{*}{$\begin{array}{c}\text { Resource } \\
\text { Allocation } \\
\text { Decsion } \\
\text { Participation } \\
\text { Level }\end{array}$} & \multicolumn{2}{|c|}{ Professional Certification } & \multicolumn{3}{|c|}{ Experience } & \multicolumn{3}{|c|}{ Size Of The Firm } \\
\hline & Yes & No & 1-7 Years & 8-15 Years & $\begin{array}{c}\text { Over } 15 \\
\text { Years }\end{array}$ & Small & Medium & Large \\
\hline 1 & $5(4.42)$ & $4(3.54)$ & $3(2.65)$ & $6(5.31)$ & $0(0.00)$ & $2(1.77)$ & $2(1.77)$ & $5(4.42)$ \\
\hline 2 & $18(15.93)$ & $2(1.77)$ & $2(1.77)$ & $7(6.19)$ & $11(9.73)$ & $3(2.65)$ & $4(3.54)$ & $13(11.50)$ \\
\hline 3 & $19(16.81)$ & $6(5.31)$ & $6(5.31)$ & $10(8.85)$ & $9(7.96)$ & $10(8.85)$ & $8(7.08)$ & 7 (6.19) \\
\hline 4 & $25(22.12)$ & $4(3.54)$ & $3(2.65)$ & $10(8.85)$ & $16(14.16)$ & $6(5.31)$ & $12(10.62)$ & $11(9.73)$ \\
\hline 5 & $25(22.12)$ & $5(4.42)$ & $4(3.54)$ & $15(13.27)$ & $11(9.73)$ & $13(11.50)$ & $8(7.08)$ & $9(7.96)$ \\
\hline Total & $92(81.42)$ & $21(18.58)$ & $18(15.93)$ & $48(42.48)$ & $47(41.59$ & $34(30.09)$ & $34(30.09)$ & $45(39.82)$ \\
\hline Chi-Square & \multicolumn{2}{|c|}{5.949} & \multicolumn{3}{|c|}{12.501} & \multicolumn{3}{|c|}{$12.726^{*}$} \\
\hline
\end{tabular}

Significant at $5 \%$ level

Note: Due to missing values, the number of responses may not add up to 118 .

\section{Factor Analysis Results}

The results of the orthogonally rotated factor analysis are presented in Table 6 . The results clearly show that there are two factors: one participation factor and another MIS-budgeting factor. Generally, a variable with a coefficient greater than 0.50 is considered relevant for a given factor. Thus, in terms of importance, the variables in the participation factor are:

- $\quad$ Participation in strategic planning

- New product introduction participation

- Resources allocation participation

- $\quad$ Product discontinuance decisions

- $\quad$ Financing decisions and

- $\quad$ Participation in marketing decisions.

Factor analysis, thus, shows that the accountants' most important role is in strategic planning followed by new product introduction, resource allocation, product discontinuance, financing and marketing decisions. Participation factor has an explained variance of $62.97 \%$. Thus, the first factor is more important in explaining the total variance from the specified model. The second factor, the MIS-budgeting factor consists of:

- Usefulness of the budget

- $\quad$ Level of top management support

- $\quad$ Participation in MIS decisions and

- $\quad$ Participation in Personnel decisions.

Thus, for the MIS-budgeting factor, usefulness of the budget is the most important variable followed by top management support level, and participation in MIS decisions. It is interesting to note that budgeting and MIS decision involvement are linked: one needs a lot of input from MIS to reach various budgeting decisions.

\section{Cluster Analysis Results}

The results from the cluster analysis are presented in Tables 7 and 8 . Table 7 provides summary results. As one can see, there are two clusters, one with eight variables, and the other with four variables. Cluster 1 explains $60.14 \%$ of the total variation while Cluster 2 explains $58.82 \%$ of the total variation. The two clusters together explain $59.70 \%$ of the total variation. Individual cluster structures are presented in Table 8 . Cluster 1 is the Participation cluster and consists of eight participation variables identified in the Factor analysis earlier. Strategic planning participation variable has the highest coefficient of 0.8241 with R-squared value of $67.93 \%$ for its own cluster; new product introduction participation has a cluster coefficient of 0.81311 explaining $66.12 \%$ of the 
variation with Cluster 1. Financing decision participation variable has a coefficient of 0.7392 with an R-squared of $54.64 \%$ with its own cluster 1 . The second cluster has three variables namely, usefulness of the budget, MIS participation, and level of top management support: this cluster is the MIS-budgeting cluster. The coefficient for the usefulness of the budget is 0.8692 explaining a variation of $75.54 \%$ with its own cluster 2 .

Table 6 Factor Analysis Results

\begin{tabular}{|l|c|c|c|}
\hline \multicolumn{1}{|c|}{ Variable } & \multicolumn{2}{c|}{ Rotated Factor Pattern Coefficients } & $\begin{array}{c}\text { Communality } \\
\text { Estimate }\end{array}$ \\
\hline & Factor 1 & Factor 2 & \\
\hline 1. Strategic Planning & 0.7602 & 0.3182 & 0.6792 \\
\hline 2. New product Introduction & 0.8248 & 0.0638 & 0.6844 \\
\hline 3. Product Discontinuation & 0.7816 & 0.0374 & 0.6122 \\
\hline 4. Allocation of Resources & 0.7284 & 0.2639 & 0.6001 \\
\hline 5. Financing Decisions & 0.7276 & 0.1359 & 0.5478 \\
\hline 6. Marketing Decisions & 0.8092 & 0.0892 & 0.6628 \\
\hline 7. Production Decisions & 0.7926 & 0.0614 & 0.6319 \\
\hline 8. Personnel Decisions & 0.5798 & 0.5343 & 0.6217 \\
\hline 9. Capital Budgeting Decisions & 0.0083 & 0.6162 & 0.3798 \\
\hline 10. Level of Top Management Budget Support & 0.0794 & 0.8486 & 0.7264 \\
\hline 11. Usefulness of the Budget & 0.1099 & 0.8531 & 0.7398 \\
\hline 12. Management Information Systems & 0.2941 & 0.6456 & 0.5033 \\
\hline Variance Explained Percentage & 4.6531 & 2.7363 & \\
\hline
\end{tabular}

Table 7 Cluster Analysis Summary Results

\begin{tabular}{|c|c|c|c|}
\hline Cluster & No. Of Variables & Variation Explained & Proportion Explained \\
\hline 1 & 8 & 4.811 & $60.14 \%$ \\
\hline 2 & 4 & 2.353 & $58.82 \%$ \\
\hline Total & 12 & 7.164 & $59.70 \%$ \\
\hline
\end{tabular}

\section{Implications of Our Results}

The results of the analysis of the role of accountants in managerial decision-making in India reveal that they participate in MIS, financing and production decisions, in decisions to allocate resources, introduce new products, and discontinue existing products. These results are consistently supported by Chi-square analysis, factor analysis and cluster analysis. Professional certification, experience, and size of the firm, in general, have a significant effect on the participation of accountants in various managerial decisions.

Until recently, a substantial part of Indian industry was in the public sector. Members of the Indian Administrative Service (IAS), essentially generalists, played an important role in the decision-making process, and professional accountants and engineers at best had a minimal role in decision-making. Beginning in the nineties, the government of India started pursuing various economic liberalization policies that included opening up Indian markets to foreign investment and privatization of industries. Because of these new developments, Indian professional accountants and engineers seem to command more respect and are participating increasingly in the decision making process. Although in many ways accountants in India are still confined to traditional roles, they are beginning to make inroads into nontraditional turf. Similar to their American counterparts, they have begun to participate to a considerable extent in various managerial decisions. If this is, indeed, a serious trend, chances are that, in the not too distant future, accountants will begin to play an important part as integral members of the management team. 
Table 8 Cluster Analysis Results

\begin{tabular}{|c|c|c|c|c|}
\hline \multirow[t]{2}{*}{ Variable } & \multicolumn{2}{|c|}{$\begin{array}{c}\text { Cluster Structure } \\
\text { Coefficients }\end{array}$} & \multicolumn{2}{|c|}{ R-squared } \\
\hline & Cluster 1 & Cluster 2 & Own Cluster & Next Closet \\
\hline 1. Strategic Planning & 0.8241 & 0.3989 & 0.6793 & 0.1592 \\
\hline 2. New product Introduction & 0.81311 & 0.2193 & 0.6612 & 0.0481 \\
\hline 3. Product Discontinuation & 0.7609 & 0.1989 & 0.5789 & 0.0396 \\
\hline 4. Allocation of Resources & 0.7755 & 0.3407 & 0.6014 & 0.1161 \\
\hline 5. Financing Decisions & 0.7392 & 0.2318 & 0.5464 & 0.0569 \\
\hline 6. Marketing Decisions & 0.8049 & 0.2318 & 0.6479 & 0.0537 \\
\hline 7. Production Decisions & 0.7805 & 0.2102 & 0.6092 & 0.0442 \\
\hline 8. Personnel Decisions & 0.6980 & 0.5469 & 0.4872 & 0.2991 \\
\hline 9. Capital Budgeting Decisions & 0.168324 & 0.6121 & 0.3747 & 0.0283 \\
\hline 10. Level of Top Management Budget Support & 0.2791 & 0.6121 & 0.7432 & 0.0779 \\
\hline 11. Usefulness of the Budget & 0.3066 & 0.8692 & 0.7554 & 0.0940 \\
\hline 12. Management Information Systems & 0.4122 & 0.6925 & 0.4795 & 0.1699 \\
\hline
\end{tabular}

\section{SUMMARY AND CONCLUSIONS}

In this study, using the questionnaire survey method, we examined the participation of accountants in India in managerial decision-making. We distributed 250 questionnaires out of which 118 were returned, giving us an overall response rate of 47 percent. We collected some personal data and analyzed the participation of Indian accountants in strategic planning, new product introduction, product discontinuance, allocation of resources, financing, production, personnel, and management information systems decisions. Then, we analyzed the frequency distribution of the participation in these decision variables. We found that the greatest participation of accountants occurs in the MIS area, followed by financing decisions, production decisions, allocation of resources decisions, product discontinuance, and new product introduction decisions. Further analysis of accountants' participation in the financing decision by experience, size of firm, and professional certification shows that professional certification and experience have led to a greater degree of participation. With regard to participation in new product introduction, professional certification leads to higher participation and so does greater experience. Factor analysis showed two factors, a participation factor consisting of eight of the nine participatory variables, and a MISbudgeting factor consisting of the usefulness of budgeting, level of top management support for the budgeting process, and involvement in MIS. Our study also suggests that accountants in India are increasingly playing a strategic role in the managerial decision making process.

\section{REFERENCES}

1. Horngren, Charles T., George Foster and Srikant M. Datar, Cost Accounting: A Managerial Emphasis, $10^{\text {th }}$ edition, Upper Saddle River, NJ: Prentice Hall, 2000.

2. Lander, Gerald H., James R. Holmes, Manuel A. Tipgos and Marc J. Wallace, Jr., Profiles of the Management Accountant, Montvale, New Jersey: National Association of Accountants, 1983.

3. Latshaw, Craig A. and Yeong Choi, "The Balanced Scorecard and the Accountant as a Valued Strategic Partner," Review of Business Studies, Winter 2002, pp. $27-29$.

4. Kulesza, C. S. "Bud" and Gary Siegel, "It's Not Your Father's Management Accounting," Management Accounting, May 1997, pp. 56-59.

5. Prendergast, Paul, "Capital Projects: wishful thinking and worse," Management Accounting, November 1998, pp. 40-42.

6. Russell, Keith, Gary H. Siegel, and C. S. Kulesza, Counting More, "Counting Less: Transformations in the Management Accounting Profession,” Management Accounting Quarterly, Vol. 1, No. 1, Fall 1999, pp. 3034.

7. Siegel, Gary, "Where the Profession is Headed?" Strategic Finance, March 2001, pp. 71-72. 